\title{
Coexistence of ocular neuromyotonia and hemifacial spasm
}

自

Figure Brain MRI and video-oculography
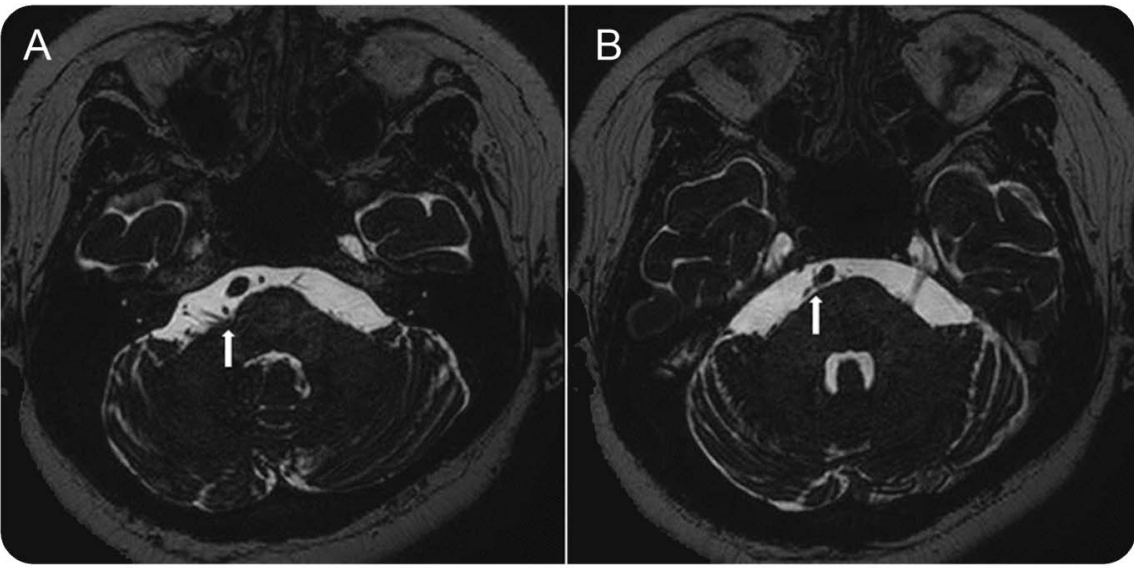

C. Horizontal gaze

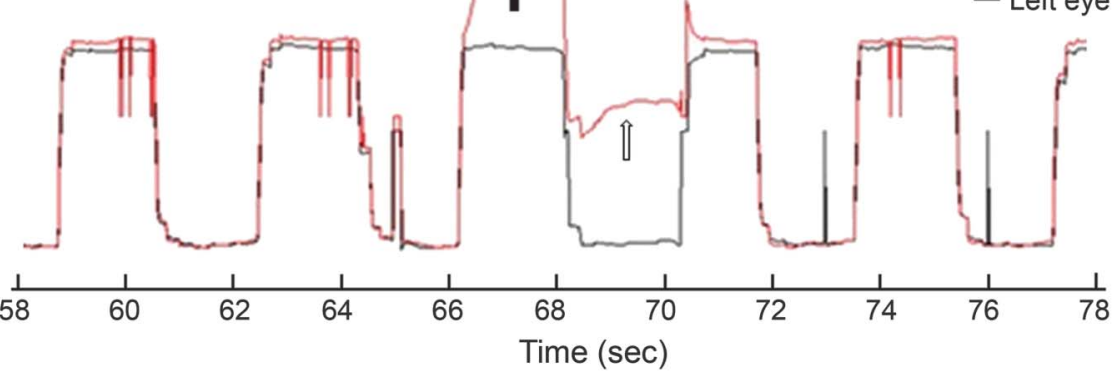

Brain MRI shows the right anterior inferior cerebellar artery intersecting with the right facial nerve $(\mathrm{A})$ and the right abducens nerve (B). (C) Video-oculography shows episodic exodeviation (black arrow) and limited adduction (white arrow) of the right eye, compatible with ocular neuromyotonia of the right lateral rectus muscle.

A 47-year-old woman presented with facial jerky movement and intermittent diplopia for 2 years. Paroxysmal deviation of the right eye was observed together with right hemifacial spasm (video on the Neurology ${ }^{\circledR}$ Web site at Neurology.org). Right anterior inferior cerebellar artery was shown to intersect with both facial and abducens nerves, and exodeviation of the right eye, compatible with ocular neuromyotonia, was recorded (figure). In ocular neuromyotonia, ephaptic neural transmission related to mechanical irritation has been suggested as its mechanism, similar to hemifacial spasm. ${ }^{1,2}$ Although 2 different terms, neuromyotonia and spasm, are used, co-occurrence of these 2 conditions in this patient suggests the similar pathophysiology in common.

Kyeong Joon Kim, MD, Jong-Min Kim, MD, PhD, Sung-Hee Kim, MD, Yun Jung Bae, MD

From Seoul National University Bundang Hospital, Seoul National University College of Medicine, Seongnam.

Author contributions: Dr. Kyeong Joon Kim contributed to data collection, data analysis, and writing the manuscript. Dr. Jong-Min Kim contributed to patient recruitment, data collection, data analysis, and writing the manuscript. Dr. Sung-Hee Kim and Dr. Yun Jung Bae contributed to data analysis.

Study funding: No targeted funding reported.

Supplemental data at Neurology.org
Disclosure: The authors report no disclosures relevant to the manuscript. Go to Neurology.org for full disclosures.

Correspondence to Dr. J.-M. Kim: jongmin1@snu.ac.kr

1. Frohman EM, Zee DS. Ocular neuromyotonia: clinical features, physiological mechanisms, and response to therapy. Ann Neurol 1995;37:620-626.

2. Ezra E, Spalton D, Sanders MD, Graham EM, Plant GT. Ocular neuromyotonia. Br J Ophthalmol 1996;80:350-355. 


\section{Neurology}

\section{Coexistence of ocular neuromyotonia and hemifacial spasm \\ Kyeong Joon Kim, Jong-Min Kim, Sung-Hee Kim, et al. \\ Neurology 2016;86;402 \\ DOI 10.1212/WNL.0000000000002322}

\section{This information is current as of January 25, 2016}

\begin{tabular}{|c|c|}
\hline $\begin{array}{l}\text { Updated Information \& } \\
\text { Services }\end{array}$ & $\begin{array}{l}\text { including high resolution figures, can be found at: } \\
\text { http://n.neurology.org/content/86/4/402.full }\end{array}$ \\
\hline Supplementary Material & $\begin{array}{l}\text { Supplementary material can be found at: } \\
\text { http://n.neurology.org/content/suppl/2016/02/02/WNL.0000000000002 } \\
\text { 322.DC1 }\end{array}$ \\
\hline References & $\begin{array}{l}\text { This article cites } 2 \text { articles, } 1 \text { of which you can access for free at: } \\
\text { http://n.neurology.org/content/86/4/402.full\#ref-list- } 1\end{array}$ \\
\hline Subspecialty Collections & $\begin{array}{l}\text { This article, along with others on similar topics, appears in the } \\
\text { following collection(s): } \\
\text { All Movement Disorders } \\
\text { http://n.neurology.org/cgi/collection/all_movement_disorders } \\
\text { Cranial neuropathy } \\
\text { http://n.neurology.org/cgi/collection/cranial_neuropathy } \\
\text { Ocular motility } \\
\text { http://n.neurology.org/cgi/collection/ocular_motility }\end{array}$ \\
\hline Permissions \& Licensing & $\begin{array}{l}\text { Information about reproducing this article in parts (figures,tables) or in } \\
\text { its entirety can be found online at: } \\
\text { http://www.neurology.org/about/about_the_journal\#permissions }\end{array}$ \\
\hline Reprints & $\begin{array}{l}\text { Information about ordering reprints can be found online: } \\
\mathrm{http} / / / \mathrm{n} \text {.neurology.org/subscribers/advertise }\end{array}$ \\
\hline
\end{tabular}

Neurology ${ }^{\circledR}$ is the official journal of the American Academy of Neurology. Published continuously since 1951, it is now a weekly with 48 issues per year. Copyright @ 2016 American Academy of Neurology. All rights reserved. Print ISSN: 0028-3878. Online ISSN: 1526-632X.

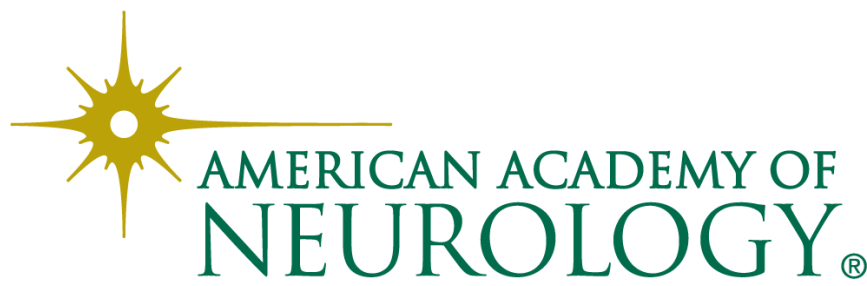

